Arq. Bras. Med. Vet. Zootec., v.62, n.3, p.615-621, 2010

\title{
Effect of deslorelin on the induction of estrus in anestrous bitches
}

\author{
[Efeito da deslorelina na indução de estro em cadelas no anestro] \\ L.L. Lanna ${ }^{1}$, A.P. Marques $J r^{2^{*}}$, R.H. Douglas ${ }^{3}$ \\ ${ }^{1}$ Aluno de pós-graduação - EV-UFMG - Belo Horizonte, MG \\ ${ }^{2}$ Escola de Veterinária - UFMG - Belo Horizonte, MG \\ ${ }^{3}$ BET Labs Inc. - Lexington-KY, USA
}

\begin{abstract}
The efficacy of one or multiple doses of an injectable formulation of deslorelin (a GnRH agonist) was evaluated to induce estrus in anestrous bitches. Thirteen animals composed three groups: group 1 ( $n=5$, single IM injection of $2 \mathrm{mg}$ deslorelin), group $2(\mathrm{n}=5$, four IM injections of $2 \mathrm{mg}$ deslorelin in alternate days), and control group ( $n=3$, four IM saline injections in alternate days). Daily clinical evaluations, sexual behavior, vaginal cytology, plasma progesterone concentration, ovaryhysterectomy and macroscopic evaluation of the uterus and ovaries were done. In group 1, none of the bitches showed signs of estrus, while two developed clinical signs and vaginal cytology of proestrus. In group 2, all animals presented proestrus, four presented estrus, and three ovulated; resulting in a functional corpus luteum and high progesterone concentration until day 25 of diestrus, when ovaryhysterectomy was performed. The duration of the stages of deslorelin induced cycles and the progesterone profile were similar to those described in the literature, and no side effects were observed. In conclusion, injectable formulation of deslorelin in multiple injections was effective to induce fertile estrus in anestrous bitches.
\end{abstract}

Keywords: bitch, deslorelin, induction of estrus

\section{RESUMO}

Avaliou-se a eficácia de uma formulação injetável de deslorelina (agonista do GnRH) na indução de estro em cadelas no anestro e seus efeitos no aparelho genital, com uma ou múltiplas aplicações. Treze animais compuseram os grupos: grupo 1 ( $n=5,2 \mathrm{mg}$ de deslorelina via IM), grupo 2 ( $n=5$, quatro injeções IM de $2 \mathrm{mg}$ de deslorelina em dias alternados) e grupo-controle (n=3, quatro injeções IM de solução salina em dias alternados). Foram realizadas avaliações clínicas diárias do comportamento sexual, da citologia vaginal, da dosagem de progesterona plasmática, da ovario-histerectomia $e$ avaliação macroscópica do útero e dos ovários. No grupo 1, as cadelas não exibiram sinais de estro, mas duas apresentaram sinais clínicos e citologia vaginal compatíveis com proestro. No grupo 2, todas apresentaram sinais de proestro, quatro de estro e três ovularam, resultando em corpos lúteos funcionais e concentração elevada de progesterona plasmática até o $25^{\circ}$ dia de diestro, quando foi realizada a ovario-histerectomia. Os sinais clínicos, a duração das fases e a curva de progesterona dos ciclos induzidos foram semelhantes aos descritos na literatura, e não foi observado efeito colateral do tratamento. Concluiu-se que a formulação injetável de deslorelina com múltiplas aplicações foi eficaz na indução de estro em cadelas em anestro.

Palavras-chave: cadela, deslorelina, indução de estro

\section{INTRODUCTION}

The control of the estrous cycle in bitches, mainly the induction and synchronization of estrus and ovulation, is fundamental for the application of assisted reproduction techniques. The development of an efficient and predictive method of estrus induction is an important step in clinical approach of infertility in the bitch, and

Recebido em 23 de julho de 2009

Aceito em 10 de maio de 2010

* Autor para correspondência (corresponding author)

E-mail: ampinho@ufmg.br 
should be useful for commercial breeding, resulting in a greater frequency and larger number of births per year. However, the lack of effective protocols of induction and synchronization of ovulation is still an obstacle for the use of reproductive biotechnology in dogs (Concannon, 2005; Kutzler, 2005).

Among the drugs currently available, gonadotrophin-releasing hormone (GnRH) agonists has shown potential for inducing a fertile estrus in bitches (Kutzler, 2007). The deslorelin, a synthetic GnRH agonist, presents potency and stability many times larger than the native hormone (Concannon, 2005), stimulating the secretion of follicle stimulating hormone (FSH) and luteinizing hormone (LH), promoting ovulation (Dyer and Robinson, 1989). Recently, an injectable short-action formulation was developed, tested firstly in mares (Berezowski et al., 2004; Stitch et al., 2004), which raised interest in the study of estrus induction in bitches (Kutzler, 2005).

Based on previous reports and in the potential of GnRH agonists in the induction of estrus in bitches, the present study evaluated the effect of an injectable intramuscular formulation of deslorelin in anestrous bitches, testing one or multiple applications in the induction of estrus and ovulation, and its effects on the reproductive system.

\section{MATERIAL AND METHODS}

Thirteen adult mongrel bitches, weighing from 10 to $15 \mathrm{~kg}$, aging from about two to seven-yearold, clinically healthy were used. They were brought from the Serviço de Controle de Zoonoses at the Secretaria Municipal de Saúde in Belo Horizonte-MG. All animals were initially characterized in anestrus by vaginal cytology, with predominance of parabasal and intermediate cells, and rare neutrophils, and by the concentration of plasmatic progesterone below $0.5 \mathrm{ng} / \mathrm{mL}$, besides the lack of clinical signs of proestrus. A male dog was used in the beginning of the experiment until the cytological characterization of diestrus to evaluate the sexual behavior of the females. During the experiment, the animals were kept in individual cages, fed with balanced commercial food and water ad libitum.
The bitches were randomly distributed in three groups: group $1(\mathrm{n}=5$, single IM injection of $2 \mathrm{mg}$ deslorelin - BET Labs Inc. - Lexington, USA), group $2(n=5$, four IM injections of $2 \mathrm{mg}$ deslorelin in alternate days); and control group ( $n=3$, four IM saline injections in alternate days). The day 0 for each animal was defined as the day of the first injection, always in the semitendinous or semimembranous muscle, with the application site being daily evaluated for the presence of edema, pain, or other alterations.

Daily, all bitches were evaluated for the presence of edema and vulvar discharge, as well as for the general clinical condition. The sexual behavior was evaluated by the attraction and receptivity to the male daily exposed to each bitch for five minutes, until the cytological characterization of diestrus.

For the cytological exam, vaginal smears were daily obtained, from the day previous to the beginning of the treatment until obtaining three consecutive smears suggesting diestrus. Following this, every three days until the end of the experiment. The smears were stained using the hematoxilin-Shorr method and evaluated by light microscopy using a 200x or 400x for the proportion of parabasal, intermediate, and superficial cells, as well as for the presence of blood red cells and neutrophils.

Blood samples were daily collected, always in the morning, from the day previous to the beginning of the treatment until diestrus, and following this, every three days until the end of the experiment. The samples were collected by the jugular vein punction, in $10 \mathrm{~mL}$ heparinized vacutainer tubes, homogenized, and centrifuged at $700 \mathrm{~g}$ for $5 \mathrm{~min}$, and the plasma was kept at $20^{\circ} \mathrm{C}$ until radioimmunoassay which was done with a commercial kit (Progesterone kit coat-acount - DPC MedLab - São Paulo, Brazil).

Ovaryhysterectomy was done on the $25^{\text {th }}$ day of diestrus post treatment in the bitches which responded to it and at 45 days in the remaining, using the technique and procedures described by Stone (2002). The uterus and ovaries were separated, weighed, and measured for the diameter and length, and the ovaries were inspected regarding the presence of follicles and corpus luteum. Complete sessions of $5 \mathrm{~mm}$ thickness of the average portion of uterine horns 
and fragments of the ovaries were collected and fixated in $10 \%$ formaldehyde for future histological evaluation.

The data were evaluated by descriptive statistics and by the Student's $t$ test at a 5\% significance level. Fisher's exact test was used to compare the treatment efficacy between the groups. The experimental protocol was approved by the Comitê de Ética em Experimentação Animal (CETEA/UFMG - protocol nº106/2007).

\section{RESULTS AND DISCUSSION}

In group 1, none of the bitches (0/5) presented signs of estrus; however, two presented bloody vulvar discharge and vulvar edema three to six days after the application of deslorelin, which persisted for three to four days, compatible with proestrus signs. Three of the bitches (3/5) attracted the male when challenged, without acceptance of courtship or mating.

In the vaginal cytology, all bitches in group 1 $(5 / 5)$ presented an increase in the proportion of superficial cells, reaching a high average of $44 \pm 15.2 \%$. Both bitches which showed clinical signs of proestrus had over $50 \%$ of superficial cells prior to a rapid decline, followed by a predominance of parabasal and neutrophil cells, compatible with diestrus or anestrus. The day of the vaginal smear with less than $20 \%$ of the superficial cells was the same as the day of the disappearance of the vaginal discharge and edema in the vulva.

The clinical, cytological, and behavioral signs of proestrus presented by two bitches in group 1 apparently are due to individual response, probably due to the luteinization of some follicles, with and initial synthesis of progesterone and release of gonadotrophins, although in concentrations not sufficient to induce estrus and ovulation.

Four bitches of group 2, treated with multiple deslorelin injections, showed characteristic signs of proestrus and estrus, including a bloody vulvar discharge, vulvar edema, acceptance of the male, and over $80 \%$ of superficial cells in the vaginal smear, differing from group 1 by Fisher's exact test $(\mathrm{P}<0.05)$. The signs of proestrus were observed four to six days after the beginning of the treatment (mean 5.0 \pm 0.8 days). The mean duration of the proestrus was $8.3 \pm 1.0$ days. The transition of the proestrus to estrus was defined as the first day in which over $80 \%$ of superficial cells were found in the vaginal cytology, and vulvar edema, with or without the vaginal discharge, besides the acceptance or not of the male. The estrus duration was $6.3 \pm 0.3$ days, while the male acceptance varied from two to six days (mean 3.0 \pm 2.2 days).

In the bitches which responded to serial injections of deslorelin, the interval between the beginning of the treatment and the appearance of estrus varied from 12 to 15 days (mean 13.3 \pm 1.5 days). The abrupt change of vaginal smear for a typical diestrus occurred $19.3 \pm 1.5$ days after the first application of deslorelin. One animal of group 2 presented bloody vaginal discharge, vulvar edema, and attraction to the male; however, only reached $65 \%$ of the superficial cells, percentage that showed a rapid fall. The appearance of proestrus occurred eight days after the beginning of the treatment and lasted only four days, when the clinical signs ended. Table 1 illustrates the responses obtained in both groups and Table 2 shows the duration of the physiological events in the animals which responded to the treatment.

Table 1. Reproductive responses in bitches treated with one $2 \mathrm{mg}$ deslorelin dose (group 1), with multiple $2 \mathrm{mg}$ doses (group 2), and saline (control group)

\begin{tabular}{lccc}
\hline Response & $\begin{array}{c}\text { Group 1 } \\
\mathrm{n}=5(\%)\end{array}$ & $\begin{array}{c}\text { Group 2 } \\
\mathrm{n}=5(\%)\end{array}$ & $\begin{array}{c}\text { Control group } \\
\mathrm{n}=3(\%)\end{array}$ \\
\hline Proestrus & $2(40)$ & $5(100)$ & $1(33)$ \\
Estrus & $0(0)$ & $4(80)$ & $0(0)$ \\
Ovulation & $0(0)$ & $3(60)$ & $0(0)$ \\
Luteal phase & $0(0)$ & $3(60)$ & $0(0)$ \\
\hline
\end{tabular}


Table 2. Appearance of reproductive events, in days, from the beginning of the treatment in bitches treated with one $2 \mathrm{mg}$ deslorelin dose (group 1), and with multiple $2 \mathrm{mg}$ doses (group 2)

\begin{tabular}{lcc} 
Event & Group 1 & Group 2 \\
\hline Proestrus & $4.5 \pm 2.1(\mathrm{n}=2)$ & $5.6 \pm 1.5(\mathrm{n}=5)$ \\
Estrus & - & $13.3 \pm 1.5(\mathrm{n}=4)$ \\
& & \\
Ovulation & - & $16 \pm 2(\mathrm{n}=3)$ \\
Diestrus & - & $19.3 \pm 1.5(\mathrm{n}=3)$ \\
\hline
\end{tabular}

In the control group, one of the bitches kept with the treated ones presented proestrus signs 35 days after the beginning of the experiment, apparently without any bioestimulation, or "dormitory effect", from other animals. The other two showed clinical signs, vaginal cytology, and sexual behavior which were compatible with anestrus during the period of the experiment.

One bitch in group 1 and two in group 2 showed pain and light edema on the site of deslorelin application, with one of them presenting discreet claudication for two days, with no alteration in disposition or appetite. No local or systemic treatment was used. No other collateral effect was observed, being the liquid formulation of deslorelin considered safe, in compliance with studies that evaluated the safety of GnRH agonists (Tarlatzis e Bili, 2004).

In all animals of group 1, it was found a discreet elevation of the plasmatic progesterone in the first days after the application of deslorelin. In three animals of this group which did not present clinical signs of proestrus, and in the other two that showed proestrus clinical signs, the progesterone values remained below $1 \mathrm{ng} / \mathrm{mL}$ following the treatment and during all days of the experiment, which suggests that one dose of deslorelin was inefficient to induce estrus in anestrous bitches. These results are similar to those previously reported, that showed the need to stimulate the bitches with GnRH for a period of seven to fifteen days in order to obtain a consistent ovarian response (Vanderlip et al., 1987; Concannon et al., 1989; Concannon et al., 1997; Kutzler, 2007).

The mean concentration of progesterone in group 1 , from days 3 to 6 after the treatment, was higher in the animals that showed proestrus than in the others $(\mathrm{P}<0.05)$. After day 15, all animals of the group presented progesterone concentration equal or below $0.1 \mathrm{ng} / \mathrm{mL}$, which remained in this value most of the time, with discreet oscillation in this period.

In group 2, four bitches (4/5) presented progesterone values above $1 \mathrm{ng} / \mathrm{mL}$, two to three days before the first clinical signs of estrus, differing from the observed in group $1(\mathrm{P}<0.05)$. Three bitches ovulated (3/5), considering the indicated by progesterone values above $4 \mathrm{ng} / \mathrm{mL}$ and later increase in the values until diestrus. These animals maintained the progesterone concentration close to or above $15 \mathrm{ng} / \mathrm{mL}$ until the $25^{\text {th }}$ day of diestrus, until they were submitted to ovaryhysterectomy and found corpora lutea, differing from those which did not present estrus $(\mathrm{P}<0.05)$. The progesterone peak in bitches in this group was $23.8 \pm 2.1 \mathrm{ng} / \mathrm{mL}$, similar to the findings by Cain et al. (1988); however, lower than that found by Concannon et al. (1975). The ovulation day was estimated as the first day in which the plasmatic progesterone surpassed the value of $4 \mathrm{ng} / \mathrm{mL}$, resulting that in three bitches the ovulation occurred on the second or third day of the induced estrus, similar to the observed by Phemister et al. (1973) and De Gier et al. (2006), $16 \pm 2$ days after the first of fourth injection of deslorelin. One animal presented clinical signs, vaginal cytology, and sexual behavior of estrus, similar to the other responsive bitches; however, it did not ovulate. The progesterone concentration increased up to $2.1 \mathrm{ng} / \mathrm{mL}, 12$ days after the beginning of the treatment, similar to the observed in the three animals which ovulated ( $P>0.05)$, when it began to decrease, returning to basal values after six days.

One bitch of group 2 presented signs of proestrus; however, did not show estrus, with the progesterone concentration near $1 \mathrm{ng} / \mathrm{mL}$ and, presumably, did not have the LH peak, which resulted in the end of proestrus. The mean progesterone concentration in this bitch was not different from those in group 1 which presented signs of proestrus; however, it was significantly different from those bitches which presented estrus after the treatment $(\mathrm{P}<0.05)$. It can be speculated that it reached basal values of progesterone recently, being in a very initial stage of anestrus and presenting inadequate $\mathrm{LH}$ stock in the hypophysis (Fernandes et al., 1987), insufficient to complete the follicular development and ovulation. Another considered 
hypothesis would be low sensibility and response of the hypophysis at the time of stimulation by the GnRH agonist (Concannon et al., 1997), as occurs during anestrus of normal bitches (Okkens and Kooistra, 2006).

It is not possible to clarify the reason for the ovulation failure in one of the bitches in group 2, although it had showed similar estrus signs as the bitches which responded with ovulatory estrus. Similar situation was described in bitches treated with LH (Concannon et al., 1989; Verstegen et al., 1997), GnRH (Cain et al., 1989; Concannon et al., 1997), or GnRH agonist (Volkmann et al., 2006). The initial progesterone increase and its subsequent decrease during estrus suggest that the LH surge was insufficient to promote ovulation of the follicles initially recruited. This phenomenon, named as "false estrus" by some authors, has been registered in spontaneous ovulation failures and does not seem to be related to the circulating estrogen, given that the vaginal cytology and sexual behavior were not altered (Concannon et al., 1997).

Of the animals in group 2, three presented proestrus, estrus, and ovulation and the development of corpora lutea similar to the described in spontaneous estrous cycles (Concannon et al., 1975; Feldman and Nelson, 2004) and cycles induced by GnRH agonists (Cain et al., 1989; Concannon et al., 1997). The response found in the present treatment $(60 \%)$ is similar or even higher than results found in previous reports (Concannon et al., 1989; Concannon et al., 1997; Verstegen et al., 1997), considering the lack of knowledge of the anestrus stage or previous fertility history of the used bitches (Volkmann et al., 2006). Tests with one or multiple applications of deslorelin had not been efficient in the induction of canine estrus (Kutzler, 2007), although preliminary results suggested the potential of the use of only one dose of the drug (Kutzler, 2005). Kutzler (2007) tested, without success, one, two, and three IM applications of $1.5 \mathrm{mg}$ deslorelin, in alternate days. It can be speculated that the response found in the present study is due to the longer treatment period and to the higher deslorelin dose used in the group 2, resulting in satisfactory stimulation of the hypophysis and induction of estrus and ovulation, differing the results found by Kutzler (2007).
The three bitches in the control group maintained progesterone concentration close to or below $0.1 \mathrm{ng} / \mathrm{mL}$ until day 35 of the experiment, differing from the observed in bitches in groups 1 and $2(\mathrm{P}<0,05)$. From that time on, two bitches continued with basal progesterone values, while one of them presented a slow and progressive increase until the end of the experiment, reaching $1.3 \mathrm{ng} / \mathrm{mL}$ on day 45 (the last dosage included in the experimental data), being the progesterone curve, the clinical and cytological signs compatible with the beginning of an estrous cycle.

The ovulation in three animals of group 2 was confirmed after ovaryhysterectomy by the presence of corpora lutea, with a total of 14 of them, with an average of $4.7 \pm 1.2$ per animal and $2.3 \pm 1.0$ per ovary, similar to the findings in estrus induced with deslorelin implants (Volkmann et al., 2006). The weight of the ovaries was significantly higher in the bitches in Group 2 that ovulated, being $2.8 \pm 0.7 \mathrm{~g}$ versus $1.2 \pm 0.5 \mathrm{~g}$ in the others, due to the contribution of the corpora lutea (Ström Holst et al., 2001). None of the bitches had corpus luteum and follicles simultaneously when examined after the ovaryhysterectomy. No difference was found in the size of the uterus among groups $(\mathrm{P}>0.05)$. The average diameter of the uterine horns was $7.0 \pm 0.8 \mathrm{~mm}, 7.4 \pm 0.6 \mathrm{~mm}$, and $6.9 \pm 0,7 \mathrm{~mm}$, in groups 1, 2, and control, respectively. The average length of the uterine horns was $9.0 \pm 1.3 \mathrm{~cm}, \quad 9.3 \pm 1.6 \mathrm{~cm}$, and $8.7 \pm 1.5 \mathrm{~cm}$, respectively in groups 1,2 , and control. In none of the animals there were macroscopic signs of pathological lesions in the genitalia.

The anestrus stage of the bitches in the present study was not characterized from the previous estrous cycle, which was not known. Due to this, it is not possible to be sure if the effect of the deslorelin injection was only on the induction of estrus or either on the reduction of interestrus intervals, as previously suggested for the effect of the anestrus stage on the treatment response (Van Haaften et al., 1994; Verstegen et al., 1999). However, in the present study, there is evidence that the deslorelin was able to induce proestrus, estrus and ovulation, when administered in a serial manner, in alternate days, with intramuscular application, in the used dose. 


\section{CONCLUSIONS}

The formulation of $2 \mathrm{mg}$ deslorelin proved to be effective in the induction of estrus in anestrus bitches, when administered in alternate days, via intramuscular and in a total of four applications. The estrus induced by deslorelin, in its clinical characteristics, was similar to the spontaneous estrus described in the literature.

\section{REFERENCES}

BEREZOWSKI, C.J.; STITCH, K.L.; WENDT, K.M. et al. Clinical comparision of 3 products available to hasten ovulation in cyclic mares. $J$. Equine Vet. Sci., v.24, p.231-233, 2004.

CAIN, J.L.; LASLEY, B.L.; CAIN, G.R. et al. Induction of ovulation in bitches with pulsatile or continuous infusion of GnRH. J. Reprod. Fert., suppl.39, p.143-147, 1989.

CONCANNON, P.W. Estrus induction in dogs: approaches, protocols and applications. In: WORLD CONGRESS OF THE WORLD SMALL ANIMAL VETERINARY ASSOCIATION, 30., 2005, Mexico. Proceedings... Mexico: WSAVA, 2005.

CONCANNON, P.W.; HANSEL, W.; VISEK, W.J. The ovarian cycle of the bitch: plasma estrogen, LH and progesterone. Biol. Reprod., v.13, p.112-121, 1975.

CONCANNON, P.W.; LASLEY, B.; VANDERLIP, S. LH release, induction of oestrus and fertile ovulations in response to pulsatile administration of GnRH to anoestrous dogs. J. Reprod. Fert., suppl.51, p.41-54, 1997.

CONCANNON, P. W.; McCANN, J. P.; TEMPLE, M. Biology and endocrinology of ovulation, pregnancy and parturition in the dog. J. Reprod. Fert., suppl.39, p.3-25, 1989.

De GIER, J.; KOOISTRA, H.S.; DJAJADININGRAT-LAANEN, S.C. et al. Temporal relations between plasma concentrations of luteinizing hormone, folliclestimulating hormone, estrogen-17 $\beta$, progesterone, prolactin and $\alpha$-melanocytestimulating hormone during the follicular, ovulatory and early luteal phase in the bitch. Theriogenology, v.65, p.1346-1359, 2006.
DYER, R.G.; ROBINSON, J.E. The LHRH pulse generator. J. Endocrinol., v.123, p.1-2, 1989.

FELDMAN, E.C.; NELSON, R.W. Canine and feline endocrinology and reproduction. 3.ed. Philadelphia: W.B. Saunders, 2004. 1089p.

FERNANDES, P.A.; BOWEN, R.A.; KOSTAS, A.C. et al. Luteal function in the bitch: changes during diestrus in pituitary concentration of and number of luteal receptors for luteinizing hormone and prolactin. Biol. Reprod., v.37, p.804-811, 1987.

KUTZLER, M.A. Estrus induction and synchronization in canids and felids. Theriogenology, v.68, p.354-374, 2007.

KUTZLER, M.A. Induction and synchronization of estrus in dogs. Theriogenology, v.64, p.766$775,2005$.

OKKENS, A.C.; KOOISTRA, H.S. Anoestrus in the dog: a fascinating history. Reprod. Dom. Anim., v.41, p.291-296, 2006.

PHEMISTER, R.D.; HOLST, P.A.; SPANO, J.S.; et al. Time of ovulation in the beagle bitch. Biol. Reprod., v.8, p.74-82, 1973.

STITCH, K.L.; WENDT, K.M.; BLANCHARD, T.L. et al. Effects of a new injectable short-term release deslorelin in foal-heat mares. Theriogenology, v.62, p.831-836, 2004.

STONE, E.A. Ovary and uterus. In: SLATTER, D.H. (Ed.) Small animal surgery. 3.ed. Philadelphia: W.B Saunders, 2002. p.1487-1502.

STRÖM HOLST, B.; LARSSON, B.; RODRIGUEZ-MARTINEZ, $\mathrm{H}$. et al. Prediction of the oocyte recovery rate in the bitch. J. Vet. Med., v.48, p.587-592, 2001.

TARLATZIS, B.C.; BILI, H. Safety of GnRH agonists and antagonists. Expert Opin. Drug Saf., v.3, p.39-46, 2004.

VAN HAAFTEN, B.; BEVERS, M.M.; VAN DEN BROM, W.E. et al. Increasing sensitivity of the pituitary to $\mathrm{GnRH}$ from early to late anoestrus in the beagle bitch. J. Reprod. Fert., v.101, p.221-225, 1994. 
VANDERLIP, S.; WING, A.; LINKE, D. et al. Ovulation induction in anestrous bitches by pulsatile administration of gonadotrophin releasing hormone (GnRH). Lab. Anim. Sci., v.37, p.459-464, 1987.

VERSTEGEN, J.P.; ONCLIN, K., SILVA, L.D.M. et al. Effect of stage of anestrus on the induction of estrus by dopamine agonist cabergoline in dogs. Theriogenology, v.51, p.597-611, 1999.
VERSTEGEN, J.P.; ONCLIN, K., SILVA, L.D.M. et al. Termination of obligate anoestrus and induction of fertile ovarian cycles in dogs by administration of purified pig LH. J. Reprod. Fert., v.111, p.35-40, 1997.

VOLKMANN, D.H.; KUTZLER, M.A.; WHEELER, R. et al. Failure of hCG to support luteal function in bitches after estrus induction using deslorelin implants. Theriogenology, v.66, p.1502-1506, 2006. 